Post-I99o Documentary 



\section{Post-I990 Documentary}

Reconfiguring Independence

Edited by Camille Deprez and Judith Pernin 
(C) editorial matter and organisation Camille Deprez and Judith Pernin, 2015

(C) the chapters, their several authors, 2015

Edinburgh University Press Ltd

The Tun - Holyrood Road

I2 (2f) Jackson's Entry

Edinburgh EH8 8PJ

www.euppublishing.com

Typeset in I I/I3 Monotype Ehrhardt by

Servis Filmsetting Ltd, Stockport, Cheshire, and printed and bound in Great Britain by

CPI Group (UK) Ltd, Croydon CRo 4 YY

A CIP record for this book is available from the British Library

ISBN 978 o 7486 9413 6 (hardback)

ISBN 978 o 7486 94I 43 (webready PDF)

ISBN 978 I 47440387 o (epub)

The right of the contributors to be identified as authors of this work has been asserted in accordance with the Copyright, Designs and Patents Act I988 and the Copyright and Related Rights Regulations 2003 (SI No. 2498). 